\title{
Andrzej Suchcitz
}

Londyn

Instytut Polski i Muzeum im. Gen. Sikorskiego

\section{Dokumenty wydobyte $z$ morza po katastrofie gibraltarskiej}

Interesujące jest to, że mimo wielu prac napisanych o generale Władysławie Sikorskim - wojennym premierze i Naczelnym Wodzu, mimo ogromu badań przyczyn i przebiegu katastrofy pod Gibraltarem, w której zginął z całą swoją świtą 4 lipca 1943 r., mało kto zainteresował się dokumentami wyłowionymi z wraka samolotu. Gwoli ścisłości należy stwierdzić, że nie ma ich aż tak dużo. Stąd też trudno stwierdzić, jaki to stanowi procent wiezionych wówczas akt. Niemniej stanowią one jakby swoistą klamrę czasową życia generała Sikorskiego i dają nam możność zapoznania się z zagadnieniami, jakimi zajmował się przede wszystkim w ostatnich tygodniach i dniach życia, podczas podróży inspekcyjnej Wojska Polskiego na Środkowym Wschodzie ${ }^{1}$.

Akta te, wydobyte $\mathrm{z}$ morza $\mathrm{z}$ wyraźnymi śladami przebywania $\mathrm{w}$ wodzie, oprócz pewnych indywidualnych dokumentów, dzielą się na dwie niewielkie teczki. Są one jednak tematycznie odrębne od siebie i niezależne.

Pierwsza z nich, to akta ściśle wojskowe, podzielone na zagadnienia. Były one częściowo opracowywane przez, towarzyszących Naczelnemu Wodzowi, oficerów - gen. Tadeusza Klimeckiego - szefa Sztabu Naczelnego Wodza oraz płk. dypl. Andrzeja Mareckiego, szefa Oddziału Operacyjno-Wyszkoleniowego Sztabu Naczelnego Wodza. Dokumenty te zaczynają się od zestawienia materiałów przygotowanych dla gen. Sikorskiego specjalnie na tę podróż na Środkowy Wschód. Materiały odnalezione obejmowały szeroki wachlarz zagadnień w tym: przewidywania dotyczące powstania w Kraju i użycia sił zbrojnych będących po za Krajem na wsparcie powstania powszechnego; zagadnienie organizacji wojska polskiego na terenie Francji (tej pozycji brak), sprawozdanie z sytuacji w Kraju i w Armii Krajowej; pięć prac związanych z zakończeniem działań wojennych oraz ordre de bataille, a także organizacją PSZ na styczeń 1943.

\footnotetext{
1 Instytut Polski i Muzeum im. Gen. Sikorskiego (dalej: IPMS), KOL.1/teczki 6 i 6 a.
} 
W tym miejscu nie będę szczegółowo analizować treść owych dokumentów, ale warto zauważyć, że odnośnie wsparcia powstania to Oddział Operacyjny w swym memorandum z 15 kwietnia przyjmował jako możliwość przerzucenie, $z$ chwila rozpoczęcia powstania, na teren Kraju prawie całego lotnictwa polskiego. Będzie ono użyte przede wszystkim do bezpośredniego wsparcia oddziatów powstańczych. Nie zaspokoi to całkowicie potrzeb Kraju. W tym względzie liczymy na pomoc Aliantów, w szczególności na dostarczenie lotnictwa transportowego, bez którego w ogóle wsparcie Kraju staje się nierealne ${ }^{2}$.

Przyjmowano również ewentualność przerzucenia dywizji piechoty jako jednostki desantu powietrznego. Przewidywano na ten cel jedną z dywizji z Armii Polskiej na Wschodzie. Jak widać, plany te nader ambitne nie zawsze były ugruntowane w realiach toczącej się wojny. Pozostając chwilowo przy okupowanym Kraju, należy zwrócić uwagę na to, że w dokumencie poświęconym sprawom krajowym, obejmującym sześć załączników, jest informacja, którą wówczas dysponowano w Sztabie NW na temat obozów zagłady. Znalazły się tam m.in. informacje o niemieckim obozie w Auschwitz (Oświęcimiu). Podane w dokumencie statystyki przerażają swoimi liczbami. Wykazują, że od chwili założenia obozu do grudnia 1942 r., zginęło tam ponad 640 tysięcy ludzi. Polaków 65.000, jeńców sowieckich 26.000, Żydów 520.000 (w tym z Polski 20,000) [chyba miało być 200.000], kobiet 19.000, przeważnie Polek ${ }^{3}$.

Dane o jeńcach i robotnikach przymusowych (cywilów) w Niemczech w trzecim roku wojny wyglądały nie mniej wstrząsająco. Przyjmowano, że do wiosny 1943 było około 2 milionów Polaków wywiezionych na roboty do Niemiec, z czego sześć siódmych pracowało na roli, a jedna siódma w przemyśle. $\mathrm{W}$ tej liczbie znajdowało się ponad 300.000 kobiet.

Nic dziwnego, że wśród wyłowionej z wody dokumentacji znajdują się szczegółowe ordre de bataille wojsk polskich na Środkowym Wschodzie, jak również całości Sił Zbrojnych. Są to podstawowe dokumenty do rozważań o dalszym rozwoju armii polskiej oraz jej użycia w wojnie.

Ostatnia podróż generała Sikorskiego na Bliski i Środkowy Wschód zbiegła się z przełomowym etapem wojny. W styczniu tego roku Niemcy ponieśli sromotną klęskę pod Stalingradem, gdzie 6. Armia von Paulusa poddała się Armii Czerwonej. Na początku zaś maja wojska niemieckie i włoskie zostały definitywnie pobite w północnej Afryce i zmuszone do kapitulacji. W ten sposób otwierała się droga aliantów do przejścia z defensywy do działań ofensywnych. Warto zauważyć, że jednocześnie oznaczało to powrót na kontynent europejski.

2 IPMS, KOL.1/6a, Przewidywania dotyczące powstania w Kraju i użycia sił zbrojnych tworzonych poza Krajem, 15 kwietnia 1943.

3 IPMS, KOL.1/6a, Położenie w Kraju, s. 1. 
W tej sytuacji nic dziwnego, że wśród uratowanych dokumentów znajdują się studia odnośnie dalszych możliwych operacji, mających na celu usadowienie się mocno na kontynencie europejskim dużej części wojsk polskich, znajdujących się na Środkowym Wschodzie, które brałaby udział w tych działaniach.

Pierwsze studium, sygnowane przez płk. dypl. Andrzeja Mareckiego dotyczy inwazji na Półwysep Apeniński, którego celem miało być wyeliminowanie Włoch z wojny, a następnie opanowanie pótwyspu Apenińskiego jako podstawy do uderzenia poprzez Jugosławię celem przecięcia połączeń Rzesza-Bałkany $i$ wyjście od razu na nizine węgierska ${ }^{4}$.

Pierwszym krokiem do inwazji na Włochy miało być opanowanie Sycylii i Sardynii. Płk Marecki słusznie zauważył, że uderzenie poprzez Sycylię sprowadza sie do czołowego spychania jego podtuznych komunikacyj, podczas gdy uderzenie z Sardynii na rejon Civitavecchia na pótnoc od Rzymu... prowadzi od razu do odcięcia półwyspu mniej więcej w połowie jego ogólnej długości. Drugie studium, również sygnowane przez płk. Mareckiego jest poświęcone operacji bałkańskiej. Przyjmowało ono jako główny cel opanowanie rejonu pól naftowych w Rumunii oraz zdobycie wyjść na nizinę węgierską w rejonie Belgradu. Przewidywano możliwość desantu ze strony tureckiej Tracji, w rejon Salonik względnie na wybrzeżu Bośni i północnej Albanii ${ }^{5}$. W tym wszystkim Marecki uznał, że korzystne byłoby odczekać na zmięknięcie Włoch i zaatakować Dodekanaz, otworzyć sobie tędy drogę na morze Egejskie i zaatakować Ateny. Z drugiej strony należało wykorzystać możliwość usadowienia się w Albanii północnej i zagrozić stąd połączeniom na linii Saloniki-Belgrad. Ściągnąwszy uwagę i siły przeciwnika ku tym kierunkom, należało przejść do głównego uderzenia z tureckiej Tracji na Sofię i Ruszczuk. Po ich zdobyciu miano przejść do głównego zadania, o czym wspomniano wcześniej. Marecki uznał, że z powodu trudnych warunków komunikacyjnych dla aliantów na południe od Dunaju, bitwa o tę rzekę będzie kryzysem o znaczeniu decydującym. Istotną rolę miało tu odegrać lotnictwo bombowe, którego zadaniem było działać na obydwu kierunkach, skąd Niemcy mogli skierować odwody.

Są też dwa opracowania szefa Oddziału Operacyjnego, dotyczące możliwości działań niemieckich na froncie wschodnim w 1943, jak i możliwości ich obrony na tym froncie.

Jednak pod różnymi względami jednym z najciekawszych dokumentów z tej teczki - według wszelkiego prawdopodobieństwa teczki szefa Oddziału Operacyjnego - to półprywatny list płk dypl. Leona Mitkiewicza do płk dypl. Andrzeja Mareckiego - rozpoczętego słowami Kochany Andrzeju ${ }^{6}$. Warto zatrzymać się

4 IPMS, KOL.1/6a, Inwazja na Półwysep Apeniński - studium, 8 maja 1943.

5 IPMS, KOL.1/6a, Operacja bałkańska - studium terenowe, 30 kwietnia 1943.

6 IPMS, KOL.1/6a, List płk. dypl. Leona Mitkiewicza do płk. dypl. Andrzeja Mareckiego, 8 maja 1943. 
przy nim nieco dłużej. Mitkiewicz wówczas był przedstawicielem NaczelnegoWodza przy Combined Chiefs of Staff w Waszyngtonie, czyli Połączonych Szefów Sztabu. Stąd też koordynował prace attaché wojskowego w Waszyngtonie przy Połączonych Szefach Sztabów sił amerykańskich oraz nadzorował niejako rtm. Stefana Zamoyskiego, który był obserwatorem przy przedstawicielach brytyjskich szefów sztabów w Ameryce. Ciekawe są różne obserwacje i wnioski płk. Mitkiewicza, z którymi dzielił się z Mareckim. M.in. bez ogródek pisał: że pomimo naszych wysitków trwajacych tu już z górq rok do których $i$ Ty $w$ znacznej mierze się przyczyniteś, zrozumienie przez Sztab US naszych kardynalnych potrzeb $w$ Kraju jest nadal niedostateczne. Wyraża się to najzupetniej jasno na tle owych nieszczęsnych Liberatorów. Nikt mnie nie przekona, że Amerykanie $i$ Anglicy nie moga nam dać kilkunastu potrzebnych nam dalekosięznych samolotów, posiadając produkcję tak olbrzymiq. Zaczynam myśleć czy aby nie leży $w$ ich interesie hamowanie dostarczenia materiału do Kraju. Znamienne jest, że zawsze stawiaja na pierwszym miejscu nie nasze potrzeby i możliwości $w$ sensie operacyjnym na terenie Polski, lecz to co możemy zdziałać na polu pracy wywiadowczej. Stąd bardzo chętnie dają nam drobne rzeczy. Może się mylę, ale obecnie kiedy zaczynaja oni realizować znany Ci plan dziatania, powinni by wtaśnie nam poważnie dopomóc, jeśli biorq nasze możliwości w Kraju w rachubę

Odnośnie spraw sowieckich to trzeźwo zauważył: że na tle zatargu z Rosja wyjaśnito się dość wyraźnie, że nie powinniśmy się spodziewać zbyt wiele co do pomocy w uzyskaniu granic wschodnich. W kazdym bąd́ razie to co można zobaczyć na scenie, t.zn. w prasie nie jest dla nas ani pomyślne ani przychylne... Deklaracja Stalina z dn. 4-go maja o silnej Polsce itd jest wtaśnie dlatego bardzo niebezpiecznym dla nas chwytem. Jeszcze bardziej zbałamuci ludzi, którzy patrzqc na scene, a nie na kulisy doprawdy niczego już nie rozumieja, a wiedzieli i rozumieli o Polsce i o Wschodniej Europie w ogóle mikroskopijnie mało ${ }^{8}$.

Druga teczka, którą wydobyto z morza, zawiera dokumenty o całkowicie odmiennym charakterze. Stanowią one zbieraninę różnych indywidualnych depesz, listów wymienianych pomiędzy generałem Sikorskim oraz podróżującymi z nim gen. Klimeckim i płk. Mareckim a Sztabem Naczelnego Wodza w Londynie oraz dowództwem na Środkowym Wschodzie. Znajdują się tu rękopisy wysyłanych depesz, tak osobiście przygotowanych przez Naczelnego Wodza, jak i szefa Sztabu i szefa Oddziału III. Obrazują one sprawy, którymi się bezpośrednio zajmowali w tygodniach przed katastrofą, rzeczy, które ich trapiły, tak czysto służbowe, jak i bardziej osobiste dające wgląd w osobowości owych ludzi.

Teczka zaczyna się dziennikiem podawczym prowadzonej korespondencji, zawierającej 144 pozycje, ostatnie wyraźnie rozmyte pobytem w wodzie. Już po

\footnotetext{
7 Op. cit., s. 1.

8 Op. cit., s. 2.
} 
wydobyciu akt sporządzono wykaz liczb podawczych dokumentów, których nie odnaleziono, lecz dzięki dziennikowi podawczemu wiemy, jakie były to dokumenty ${ }^{9}$. Prześledzenie każdego dokumentu wymaga szczegółowego omówienia, ale warto przyjrzeć się niektórym, celem zobrazowania ich charakterystyki. Zacznijmy od końca, czyli ostatniego dokumentu, najbardziej znanego, będącego podziękowaniem dla gen. Andersa oraz mniej znanego, charakteryzującego osobowość Naczelnego Wodza. Ten ostatni również adresowany był do gen. Andersa. Naczelny Wódz prosił w depeszy z 3 lipca, aby w jego imieniu podziękować czołówce artystycznej Armii Polskiej na Wschodzie za jej pożytecznq dla armji prace i w uznaniu ich wkładu przyznał sumę 500 funtów na polepszenie warunków bytu zespołu artystycznego ${ }^{10}$.

Prezydentowi, Władysławowi Raczkiewiczowi depeszował jeszcze z Kirkuku 4 czerwca, że nabierał coraz większego przekonania, że armia ta jest moralnie zdrowa, na która liczyć możemy w chwili próby. Bardzo nieliczne jednostki, które mogłyby zburzyć spokój pracy zostanq stąd usunięte. Bardziej ostrożną ocenę dał gen. Klimecki, depeszując swemu zastępcy w Londynie: tu duża zmiana nastroi na korzyść. Watpię by była szczera. Konieczne duże zmiany personalne, które $N W$ częściowo już aprobowat ${ }^{11}$.

Dużo depesz dotyczy bieżących spraw personalnych tak odnośnie spraw odznaczeniowo-awansowych, jak i różnych zmian personalnych. Najciekawsza z nich doprowadziła do różnicy zdań między dwoma starymi przyjaciółmi, t.j. gen. Sikorskim a generałem Marianem Kukielem - Ministrem Obrony Narodowej. Generał Sikorski chciał koniecznie przenieść ze Środkowego Wschodu gen. Michała Karaszewicza-Tokarzewskiego, zastępcę dowódcy APW i zamierzał mianować go szefem Administracji Polskich Sił Zbrojnych na miejsce gen. Mieczysława Norwid-Neugebauera. Pytał więc gen. Kukiela o jego opinię. Kukielowi nie było to po myśli i depeszował, że nie może zamienić lojalnego i kompetentnego wspótpracownika na mniej pewnego pod obu względami. Premier i Naczelny Wódz, gen. Sikorski nie miał jednak zamiaru ulec swojemu ministrowi i powtórzył swoją decyzję, pisząc m.in.: Jeśli innego zajęcia nie znajdziesz dla powszechnie nie lubianego Norwida trzeba będzie zwolnić go w stan nieczynny ${ }^{12}$.

Ideę powierzenia Tokarzewskiemu bliżej nieokreślonego stanowiska dowódcy okupacyjnego w przyszłości Naczelny Wódz wyśmiał, stwierdzając, że Nikt nie da się nabrać na istotę ważności tej koncepcji. Nie chodzi o skończenie T

9 IPMS, KOL.1/6b, dziennik podawczy.

10 IPMS, KOL.1/6b, L.p.142, rkps depeszy do gen. W. Andersa od Naczelnego Wodza, 3 lipca 1943.

11 IPMS, KOL.1/6b, L.p.26, depesza gen. Sikorskiego do Prezydenta RP, 4 czerwca 1943; L.p.42, depesza (rkps) gen. T. Klimeckiego do Ministra Obrony Narodowej i zastępcy szefa Sztabu NW, 8 czerwca 1943.

12 IPMS, KOL.1/6b L.p.48 i 69, rkps depesz NW do gen. M. Kukiela, 6 i 16 czerwca 1943. 
[czyli gen. Tokarzewskiego], jest on pierwszym dca ZWZ [sic! - gen. Tokarzewski był twórcą i dowódcą pierwszej podziemnej organizacji wojskowej pod nazwą Służba Zwycięstwu Polski. Natomiast gen. Sikorski po utworzeniu ZWZ mianował gen. Tokarzewskiego komendantem ZWZ na teren okupacji sowieckiej] $i$ jego organizatorem, zachowywat się $w$ Rosji $w$ więzieniu bez zarzutu $i$ nadal nic konkretnego zarzucić mu nie można. Z Armii na Wschodzie powinien odejść $z$ innych przyczyn. Przyczyn tych Naczelny Wódz nie sprecyzował, zapowiadając, że szczegóły omówi po powrocie ${ }^{13}$.

W wyłowionych depeszach widać plejadę przeróżnych zagadnień i problemów, z którymi borykał się Naczelny Wódz. Jak widać z powyższych przykładów, szczególną troską były sprawy personalne i to na różnym szczeblu. Wyżej mieliśmy przykład zamierzeń poważnych zmian na najwyższych stanowiskach w Armii. Innym i nie mniej ciekawym zjawiskiem wśród tych dokumentów, jest list biskupa polowego Wojska Polskiego, Józefa Gawliny, datowany półtora tygodnia przed katastrofą. Biskup Gawlina zwięźle przedstawił historię swego niedoszłego awansu na generała dywizji. Etatowym stanowiskiem biskupa polowego był stopień generała dywizji, ale Gawlina w 1933 r. przyjął stopień generała brygady na żądanie Marszałka Józefa Piłsudskiego. Żądanie to Piłsudski tłumaczył względami państwowych trudności finansowych. Podczas tej ostatniej podróży inspekcyjnej na Środkowym Wschodzie Naczelny Wódz - jak to zaznaczył ksiądz biskup Gawlina - zapowiedziat mi awans, nie dodając żadnych od siebie warunków co sobie wysoce cenię. Celem uniknięcia jednak komentarzy, które $w$ naszej atmosferze stanowisko moralne Pana Generała i moje podrywać by mogły, proszę Pana Generała o zaniechanie awansu mojego na generała dywizji. Osobiście Panu Generałowi jestem wdzięczny, że miat zamiar przywrócić stan prawny, a co do reszty sadze, że na dotychczas zajmowanym stopniu zaoszczedzając Polsce wydatków, będę mógt nadal w miarę sit służyć Bogu i Ojczyźnie ${ }^{14}$.

Sporo depesz dotyczyło sytuacji krajowej, m.in. irytacji gen. Stefana Roweckiego - „Grota” wobec intryganctwa wicepremiera Stanisława Mikołajczyka, który „ostrzegał” Roweckiego przed ostatnio wysłanym emisariuszem, jako że był człowiekiem sanacji (mowa o płk. dypl. Kazimierzu Iranek-Osmeckim). Część depesz dotyczy spraw uzyskania uzupełnień dla wojska spośród Polaków, jeńców z armii niemieckiej, pobitej w północnej Afryce. Liczono tu na wsparcie Amerykanów i Anglików w tej kwestii.

Słowem, badacz znajdzie tu wszystko, co mogło interesować gen. Sikorskiego jako Naczelnego Wodza. Rzadko znajdują się dokumenty o charakterze czysto politycznym, pokazyjącym Sikorskiego jako premiera. Widać, że inspekcja na Środkowym Wschodzie była traktowana wyłącznie z punktu widzenia woj-

13 IPMS, KOL.1/6b, L.p.82 depesza szyfr NW do Ministra Obrony Narodowej, 21 czerwca 1943.

14 IPMS, KOL.1/6b, List bp. J. Gawliny do Naczelnego Wodza, 25 czerwca 1943. 
skowego. Jako że są to depesze bieżące, nie dziw, że znajdują się także o treści wybitnie osobistej, pokazujące Sikorskich jako rodzinę. A więc zaniepokojenie Heleny Sikorskiej odnośnie choroby córki i zapewnienie, że pod opieką lekarza gen. Bolesława Szareckiego wyzdrowiała lub informacja Heleny Sikorskiej z 23 czerwca, która pisała: cieszę się bardzo, że czujecie się dobrze i może troche odpoczniecie. U mnie wszystko w porzqdku. 5.VII przeprowadzam się do nowego domu. Serdeczne ucałowania. Jedenaście dni później ani mąż, ani córka, jak i towarzyszący w podróży współpracownicy, nie żyli. Pozostała pamięć i owa garstka pamiątek i dokumentów wydobytych z morza.

\section{Documents retrieved from the sea after the Gibraltar catastrophe}

It remains an intriguing question, why all General Sikorski's biographers and those seemingly concerned about the circumstances of his death, have during the past sixty years ignored the contents of those documents which were retrieved from the sea off Gibraltar following the fateful crash of Liberator AL 523 on 4th July 1943 a few minutes past 23.00 hours.

This paper given at the Polish Embassy in London on the 70th anniversary of General Sikorski's death tries to fill in this historical gap. Several papers saved from the sea refer to the Operations Bureau of the Polish General Staff under Col. Andrzej Marecki. There are studies relating to the possible operations in Italy and the best manner of carrying them out. The overriding interest, in Polish eyes at least, was an offensive through the Balkans, which also receives a detailed paper. There are detailed papers on the situation on the eastern front, along with possible developments there. Several of these documents concentrate on the Polish Home Army (resistance movement). General Sikorski's file contains his numerous ciphers - military, political as well as private - which he sent and received in the weeks leading up to his death. The papers help to understand and unravel General Sikorski not only as Commander-in-Chief of the Polish Armed Forces and Prime Minister, but above all, as a ground commander and private man.

Key words: Gibraltar, catastrophe, General Sikorski 